\title{
International Student Mobility: An Empirical Study Based on FEUP Mechanical Engineering Data
}

\author{
Catarina F. Castro * (D) and Manuel R. Barbosa \\ Faculty of Engineering, University of Porto, Rua Dr. Roberto Frias, s/n, 4200-465 Porto, Portugal; \\ mbarbosa@fe.up.pt \\ * Correspondence: ccastro@fe.up.pt
}

check for updates

Citation: Castro, C.F.; Barbosa, M.R. International Student Mobility: An Empirical Study Based on FEUP Mechanical Engineering Data. Educ. Sci. 2021, 11, 36. https://doi.org/ 10.3390/educsci11020036

Received: 27 November 2020

Accepted: 18 January 2021

Published: 21 January 2021

Publisher's Note: MDPI stays neutral with regard to jurisdictional claims in published maps and institutional affiliations.

Copyright: (c) 2021 by the authors. Licensee MDPI, Basel, Switzerland. This article is an open access article distributed under the terms and conditions of the Creative Commons Attribution (CC BY) license (https:/ / creativecommons.org/licenses/by/ $4.0 /)$.

\begin{abstract}
Students are formal learners seeking documented and recognized tertiary education Student mobility in higher education can be inward (into a country) or outward (out of a country). Both types of mobility are educational processes offering different experiences and resulting in different outcomes. At least half of MIEM (Integrated Mechanical Engineering master degree of the Faculty of Engineering of the University of Porto, Porto, Portugal) students are driven to seek different institutions and different societies outside their known environment. During the academic year 2019/20 one hundred and forty MIEM students were engaged on exchange mobility projects distributed among inward Portuguese universities and a large number of outward European and non-European programs. This report focuses on MIEM student exchange aiming to share collected data based on numbers and experiences. A developed questionnaire addressing exchange mobility benefits on student educational progression as well as on the foreseen future career was handled to all 2019/20 mobility students and the collected data are reported here. Results of the survey show that $90 \%$ of the responding students consider that the engaged exchange program will turn into a positive influence on their career and a short $10 \%$ did not appreciate the mobility experience.
\end{abstract}

Keywords: student exchange; international student mobility; higher education; learning mechanism; globalization

\section{Introduction}

Higher education drives and is driven by internationalization and globalization. The current global context, in which technologies and advances allow the interaction with any subject, physically or virtually, has blurred the boundaries between people multiplying the relational and coexistence processes between different cultures. There is a need to promote socio-cultural coexistence and the concept of international student mobility works very closely to achieving such goal [1,2]. This social dimension and increased diversity require adaptations in the management of internationalization within contexts of higher education [3,4]. Higher education institutions have the societal responsibility of providing guidance to students, faculty, staff, and administration [5] and their decisions affect the economic, social, and environmental dimensions of the communities and regions around them [6]. Universities are central players and important economic actors in many regions and understanding the potential role that universities can play could help address global challenges.

There is evidence proving that studying abroad helps a person to cope more successfully with increasing international dimensions at work and helps with career enhancement, in general [7]. Also, it helps to improve international competences, enabling former students to be placed in visible international professional positions [8] and increases the probability of a person working abroad later in life [9]. It is no denying that international student flow is an efficient way of attracting future needed talents, and countries aiming to attract talents from other countries can benefit from offering education for international 
students. Countries aiming to attract talents from other countries should pay attention to attract international students and encourage them to seek career in local job markets after finishing study [10]. In a larger, more unified market, beneficial effect of student mobility will occur if student mobility choice of host university is guided by quality considerations [11]. Nevertheless, all approaches to internationalization are partial and must consider what is viable, relevant, and socially responsible in a given context [12].

International student mobility can be divided into two non-exclusive groups: international students that includes students enrolled and seeking a diploma at an institution in a foreign country and exchange students, students being currently enrolled and seeking mobility going abroad for at least one semester in a site-based program managed by their home university and provider organization. The Integrated Master in Mechanical Engineering (MIEM) at FEUP (Faculty of Engineering of the University of Porto, Porto, Portugal) is a five-year degree and accounts for a number of international students most of them coming from Portuguese-speaking countries such as Brazil, Angola, or Mozambique among others. Every student enrolled in the third year of MIEM can apply for an international experience abroad within an exchange program A student that considers attending a higher education program in a different location away from the enrolled university will bear costs to increase their future earnings and employment opportunities. Within a human capital perspective, students will prefer to attend a high-quality institution if any possible higher costs are compensated by higher returns. The bigger the economic gap, the more attractive the country may be to students owing to the desire of students to know more about other countries, in terms of their culture, lifestyle, language, and history, etc. In fact, other factors like history relations between countries and cultural relations or personal academic interests also can help to attract more students to engage in a mobility semester.

Motivating students for the necessary educational effort is a critical factor within the learning success. Designing for motivation offers ways to bridge motivation gaps, increase engagement, and drive behavior change. John Keller [13] introduced the ARCS motivational model of instructional design. The ARCS model looks at four components of motivation: attention, relevance, confidence, and satisfaction. Pushing internationalization, students are being exposed to elements of novelty, challenge and problems to solve. Establishing relevance is accomplished by enable them to enhance or apply skills they already possess. The confidence component of motivation refers to imbuing students with confidence of applying new skills or knowledge helping them to progress without becoming overwhelmed. Finally, satisfaction from learning when students are able to earn feedback and rewards.

The purpose of the project reported here is to examine how MIEM (Integrated Mechanical Engineering Master degree) students at FEUP (Faculty of Engineering of the University of Porto, Portugal) qualify their exchange mobility experience and how they assess the quality of the host universities. The paper is organized as follows: an overview of the relevant numbers of MIEM-student mobility, the presentation of a first MIEM mobility survey and its empirical results. Finally, a few remarks on how educational quality and opportunities drive toward a significantly positive effect on the size and direction of flows of student exchanged between countries.

\section{Outgoing Mobility at MIEM: General Characteristics}

Many economic, social, and other factors, like the willingness to work in foreign countries, or the acquisition of international identity or consciousness, affect the enrolment of students in a host university [14]. One of the barriers is language and the other is financial support. Within Europe financial aid is partially granted through the ERASMUS program and students seek mainly English-taught courses. Though the achieved excellent contacts with top institutions in Germany or France the language barrier makes it difficult for students to succeed German or French taught courses. Most of MIEM students are Portuguese native speakers so a reasonable percentage applies for Brazilian- or Spanishspeaking countries including the overseas South American Institutions if they manage to get 
the necessary living expenses support. Qualified students apply for European institutions enrolling then in courses and classes designed for English-speaking students. From the globalization perspective, the dominant position of English is beyond doubt. English is a part of school curriculums all over the world. In many places, English is no longer a foreign language but as "the language of globalization" $[15,16]$. Most Portuguese students learn English as a second language at a very early age since the range of multimodal resources, texts, and technologies that come into learning spaces offer new possibilities and challenges. The perceived usefulness from the perspective of information technology and the global e-digital market and ease of use of new technology influence student's attitudes [17].

The general characteristics of outgoing student mobility at MIEM is present here. Because of faculty policy, students are allocated to a particular host university by their preference and by scaling their internal student performance as measured by course grades. Free movers for studies are not allowed and free movers for internships are the ruled system. According to MIEM curriculum, the seventh semester of the degree is the most favorable period to go abroad using mobility for studies. It corresponds to the first semester of classical two-year master degrees and most courses offer introductory courses to further specialized subjects. Nowadays the number of students attending the seventh semester at MIEM is slightly over two hundred. Using data collected from the website SIGARRA of the University of Porto, Figure 1 addresses the evolution of student outflow over the period 2007-2020 with left-hand scale for ESM (European student mobility) and nESM (non-European student mobility) and right-hand scale for the total increase per year. There is no intention to reproduce Eurocentric hierarchies of knowledge and humanity by separating European from non-European destinations. The distinction is naturally done by the ERASMUS grant fully supporting a large group of European mobilities. Three trends are presented over the same picture: the ESM corresponds to the European student mobility (mainly ERASMUS mobility), the nESM corresponds to the non-European student mobility (mainly Latin-American South America countries), and the Yearly increase corresponding to the total increase on the numbers of outgoing students per year. Student mobility has been rising and the growth jumps are associated to new host university destinations either in Europe or outside Europe. These new host members exert a positive and lasting effect upon student mobility.

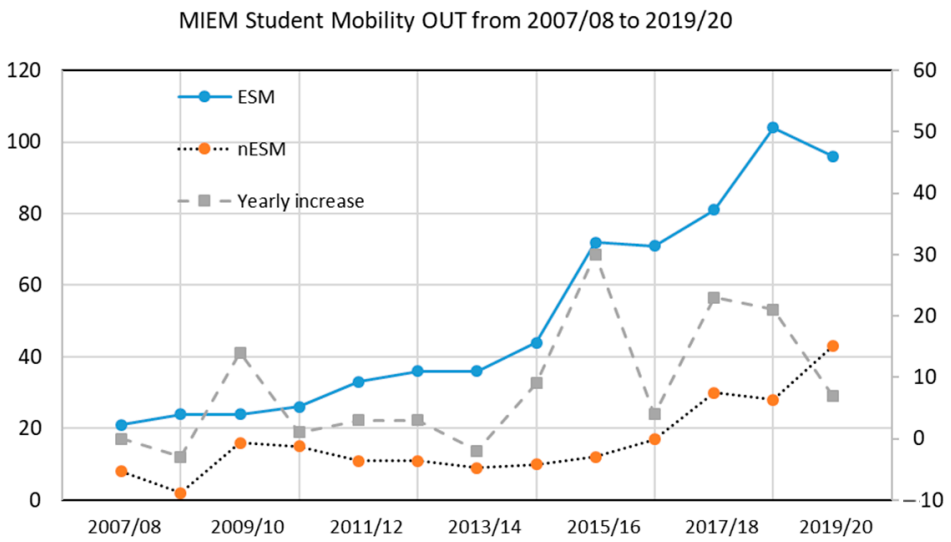

Figure 1. Evolution numbers for Integrated Master in Mechanical Engineering (MIEM) student outgoing mobility over the period 2007-2020.

From Figure 1, the total number of students applying for European Universities is double the number of students applying for non-European Universities mainly because of economic and family factors. Students selected within Europe (except Switzerland) apply for an ERASMUS grant enabling the support of their stay at the foreign country without an overload of family expenses on education. Switzerland is not a member of the European Union so exceptional rules apply. MIEM has an excellent collaboration with L' 
École Polytechnique Fédérale de Lausanne-EPFL and a Swiss grant covers nearly half of the student expenses. The other half is usually supported be student's family.

Figure 2 shows the evolution of host university offer versus the student placement demand for the same 2007-2020 period: E/nE for European/non-European student numbers. One important issue is the low-income of most Portuguese families as compared to leaving expenses at Northern European countries determining the student's selection when applying for a specific higher education institute. The demand for European host universities is always higher than the offer and only the best students manage to get a place in the best or renown universities. The demand for non-European host universities is usually lower than the offer since the travelling expenses are a handicap for most students.

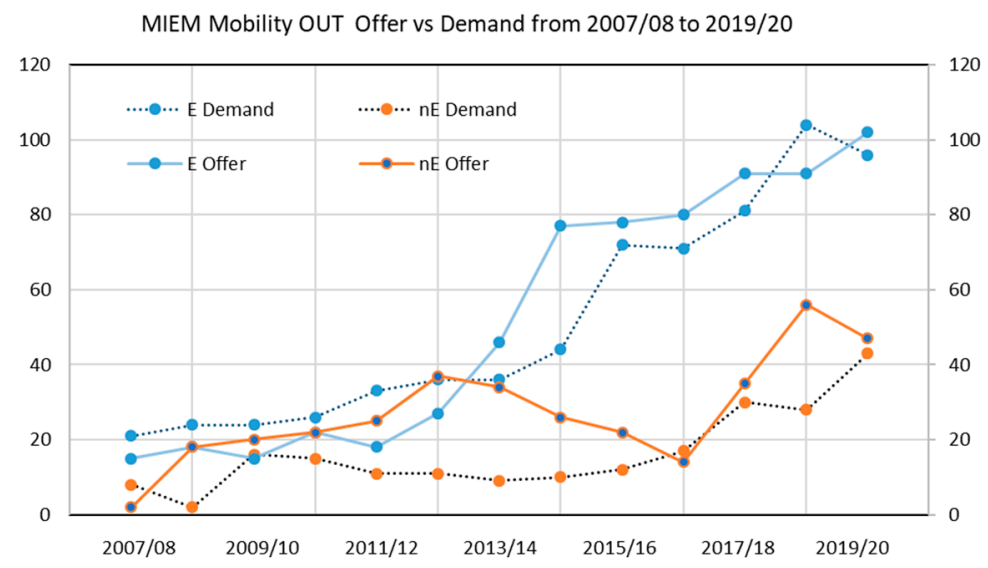

Figure 2. Evolution of demand versus offer for MIEM outgoing mobility: 2007-2020.

The European Association for International Education (EAIE) helps members to succeed professionally and to contribute to developments in international higher education from a European perspective [18]. The main goals of internationalization include: improve the quality of education; improve the quality of research; prepare students for a globalized world/enhance student employability; better service the local community and society; improve institutional reputation, competitiveness, and/or position in rankings; financial benefits; respond to demographic shifts and others. There is a need to develop deeper and more systemic understandings of the political and historical dimensions of international engagements and their possible impacts, both in general and within particular contexts. How does MIEM outgoing mobility frame these issues?

As an effort to map, examine, and contextualize different possibilities, the full list of host European countries is presented in Table 1.

Because of the large number of Erasmus agreement for studies and because of the geographic and language proximities Spain is the country with the larger number of outgoing MIEM students. Followed by Germany, France, and Italy because of the renown universities and finally Romania, Poland, and Czech Republic because of the indulged way mobility students are treated. Because of political issues the United Kingdom's figures unveil a downward trend throughout the years. So MIEM internationalization has been growing every year but not only due increase of ERASMUS learning agreements. There is an unequal partnership if one separates mobility for learning and mobility for internship. MIEM students seek mobility for learning selecting countries where language is accessible which is a handicap if MIEM offers a large majority of classes only for Portuguese-speaking students. The increase of outgoing mobility toward Northern European countries such has Sweden, Norway, Germany, and even Netherlands, is mainly due to students searching for competitiveness, position and financial benefits through internships. Internships are encouraged during the last semester of the degree mainly as part of the dissertation project. Of course, only A-level students manage a well-rewarded internship since competition for such a highly qualified place is very high. 
Table 1. Number of MIEM mobility students per European country.

\begin{tabular}{|c|c|c|c|c|}
\hline European Country & 2007/11 (4 Years) & 2011/15 (4 Years) & 2015/18 (3 Years) & $2018 / 20$ (2 Years) \\
\hline Austria & & & & 5 \\
\hline Belgium & 2 & 1 & 6 & 7 \\
\hline Bosnie-Herzégovine & & & 1 & \\
\hline Czech Republic & 6 & 12 & 13 & 10 \\
\hline Denmark & & 1 & & 3 \\
\hline Finland & 1 & & 6 & 4 \\
\hline France & 10 & 7 & 18 & 18 \\
\hline Germany & 9 & 12 & 23 & 15 \\
\hline Greece & & & 3 & 2 \\
\hline Hungary & & 2 & 6 & 4 \\
\hline Ireland & 2 & 1 & & \\
\hline Italy & 8 & 12 & 22 & 18 \\
\hline Lithuania & 7 & 7 & 6 & 4 \\
\hline Netherlands & & & 5 & 9 \\
\hline Norway & & & 5 & 1 \\
\hline Poland & 8 & 14 & 12 & 11 \\
\hline (Portugal) & & 3 & 6 & 12 \\
\hline Romania & 6 & 17 & 17 & 8 \\
\hline Serbia & & & & 1 \\
\hline Slovenia & & & 4 & 4 \\
\hline Slovakia & 7 & 8 & 8 & 4 \\
\hline Spain & 19 & 35 & 33 & 39 \\
\hline Sweden & 7 & 12 & 9 & 7 \\
\hline Switzerland & 4 & 2 & 3 & 1 \\
\hline Turkey & & & 2 & 4 \\
\hline UK & 3 & 4 & 1 & 5 \\
\hline (Total) & 104 & 151 & 210 & 270 \\
\hline
\end{tabular}

Two other prominent professional associations that support and advocate for internationalization are NAFSA, the Association of International Educators based in the United States [19], and IAU (a global association of universities) [20]. These associations are powerful by shaping internationalization as an ongoing process. One very positive issue of international programs is the fact of managing to integrate unequal partners. Portugal being a small country that cannot compete with highly industrialized countries, has so far managed to succeed when applying for grants within international programs. Moreover, so far MIEM students never encountered visa problems for being Portugal, a rather neutral country, politically speaking. The full list of host non-European countries is presented in Table 2.

Commenting on non-European host Universities the Brazilian ones are very attractive because of the cultural heritage and language facility. With the USA, MIEM has only a very short list of students applying for internship during dissertation on their last semester since the imposed course fees are prohibitive for the large majority of Portuguese students. Because of youth curiosity Eastern Asiatic academies are also on big demand, if a grant is available to support minimum acceptable living expenses.

Comparing the total number of MIEM students attending at least one semester at a host institute it is visible that the number of outgoing MIEM students has doubled during this last decade. During the academic year 2019/2020 one hundred and thirty-five students managed to apply for at least one semester at a foreign institute or university, which makes that at least half of MIEM students are driven to seek different institutions at different societies outside their known environment.

A combination of push and pull factors explains international student mobility. Push factors operate within the home country initiating the student's decision to study at a foreign country. Pull factors operate within the host country to make that country relatively 
more attractive than other potential destinations. University quality operates mainly as a pull factor level rather than as a push factor at least for European countries [21].

Table 2. Number of MIEM mobility students per non-European country.

\begin{tabular}{|c|c|c|c|c|}
\hline Non-European Country & 2007/11 (4 Years) & 2011/15 (4 Years) & 2015/18 (3 Years) & $2018 / 20$ (2 Years) \\
\hline Argentina & & 7 & 9 & 5 \\
\hline Brazil & 36 & 29 & 36 & 30 \\
\hline Chile & & & 4 & 12 \\
\hline China & & 1 & 11 & 6 \\
\hline Colombia & & & 2 & 7 \\
\hline Ecuador & & & 1 & \\
\hline India & & & & 2 \\
\hline Malaysia & & 1 & & \\
\hline Mexico & & & 5 & 2 \\
\hline Panama & & & 3 & 2 \\
\hline Peru & & & 2 & 6 \\
\hline South Korea & & & 2 & \\
\hline Taiwan & & 1 & 2 & 1 \\
\hline Thailand & & & & 1 \\
\hline USA & 1 & 2 & 3 & \\
\hline Uruguay & & & & 4 \\
\hline (Total) & 37 & 41 & 84 & 75 \\
\hline
\end{tabular}

Most of the students applying for outgoing mobility have expectations. The possibility of an exchange mobility semester where students encounter a different social environment is an attractiveness for tired students with overloaded tasks at their home universities. Questions like "what foreign faculties offer a different way of teaching that suits my personality?", "what other Mechanical Engineering faculty offer different courses and classes that suits my curiosity for my future as an engineer?" or even "what renown institutes will allow me to improve my curriculum towards a rewarding job?", are on the mind of most students. Was their mobility experience up to their expectations? In order to answer those questions, a survey has been developed and results are presented in the next section.

\section{Outgoing Mobility at MIEM: A First Survey with Quantitative Results}

In order to understand the way students were affected (positively or negatively) by their decision of an academic period outside their safe faculty environment, a survey was provided to the cohort of MIEM students who were engaged in mobility exchange during the academic year 2019/2020. One hundred and thirty-nine students received an email with a survey organized in three main topics plus an open question/remark for comments and/or recommendations. Ten questions were to be answered on a scale from 1 to 7,1 being the lowest score and 7 the highest one. Ninety-one students graciously replied, and report of their answers is considered here. The first topic intended to address the impact of their mobility on the progression of the degree studies, the second topic of the survey intended to address the impact of mobility on their training as an engineer and the third topic an account of their experience at the host university.

Topic 1. Impact on MIEM course:

Q1. Did your mobility studies restrict (narrow) your choice of MIEM specialization?

Q2. Did the study plan carried out during your mobility stay allowed you to acquire the necessary knowledge to carry out successfully the following semester at FEUP?

Q3. The study plan carried out during your mobility can be seen positive for your study plan progression at MIEM?

Figure 3 reports the results for this inquest. 

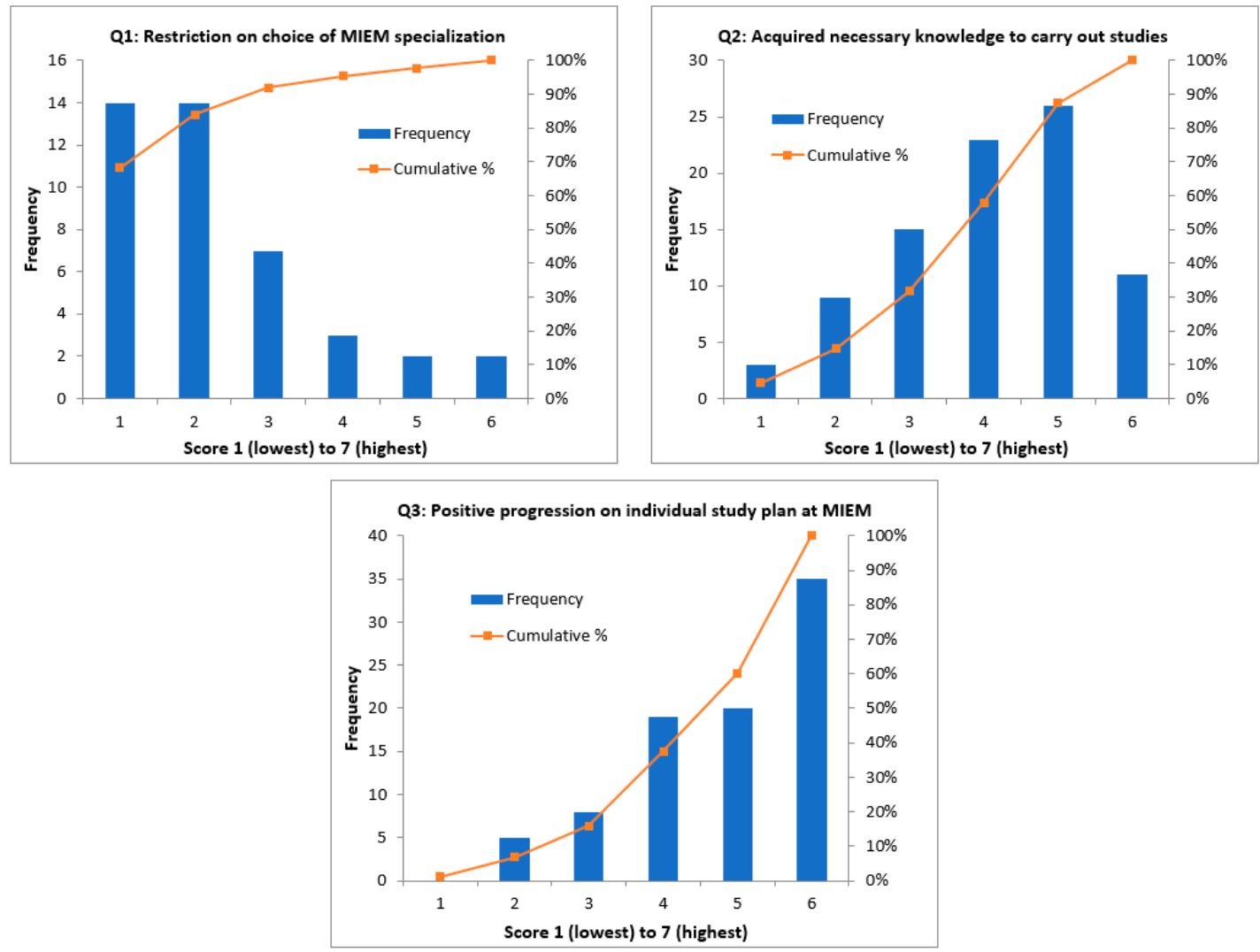

Figure 3. Collected data for Topic 1: Impact of the exchange program on MIEM studies.

Half of the students felt that the exchange period of studies did not affect at all their choice of specialization and less than ten percent had to change the foreseen specialization due to the selected exchange study program or acknowledgement of a new area of interest. As for the acquired knowledge to continue the studies at MIEM, unfortunately ten percent answered that the exchange period was useless and fifteen percent were unsure. Forty percent were happy with the exchange study program to pursue the studies back at FEUP. Finally, pushing internationalization offers ways to bridge motivation gaps and increase engagement and sixty percent of the students considered mobility as having a positive impact on their degree studies toward the final diploma.

Although most students did not have previous working experience, every student had an expectation toward what future will bring up to them as career. The second topic of the survey addresses the impact of mobility on their training as a future engineer.

Topic 2. Impact on training Engineer:

Q4. Do you consider that mobility valued your ability to deal with new situations?

Q5. Do you consider that your capacity to face the labor market has increased?

Q6. Has your predisposition to work abroad increased?

Figure 4 reports the results for this second topic. Seventy percent of the students value the exchange period toward facing unexpected situations and labor market. It is expected of an engineer not to repeat developed tasks but to improve procedures and overcome encountered problems. Exchange mobility period for a student will certainly enforce that request. Also, regarding the question of searching for a job outside their safe home environment fifty percent of the students agreed that felt confident of an increase on the possibility of working abroad later in life. 

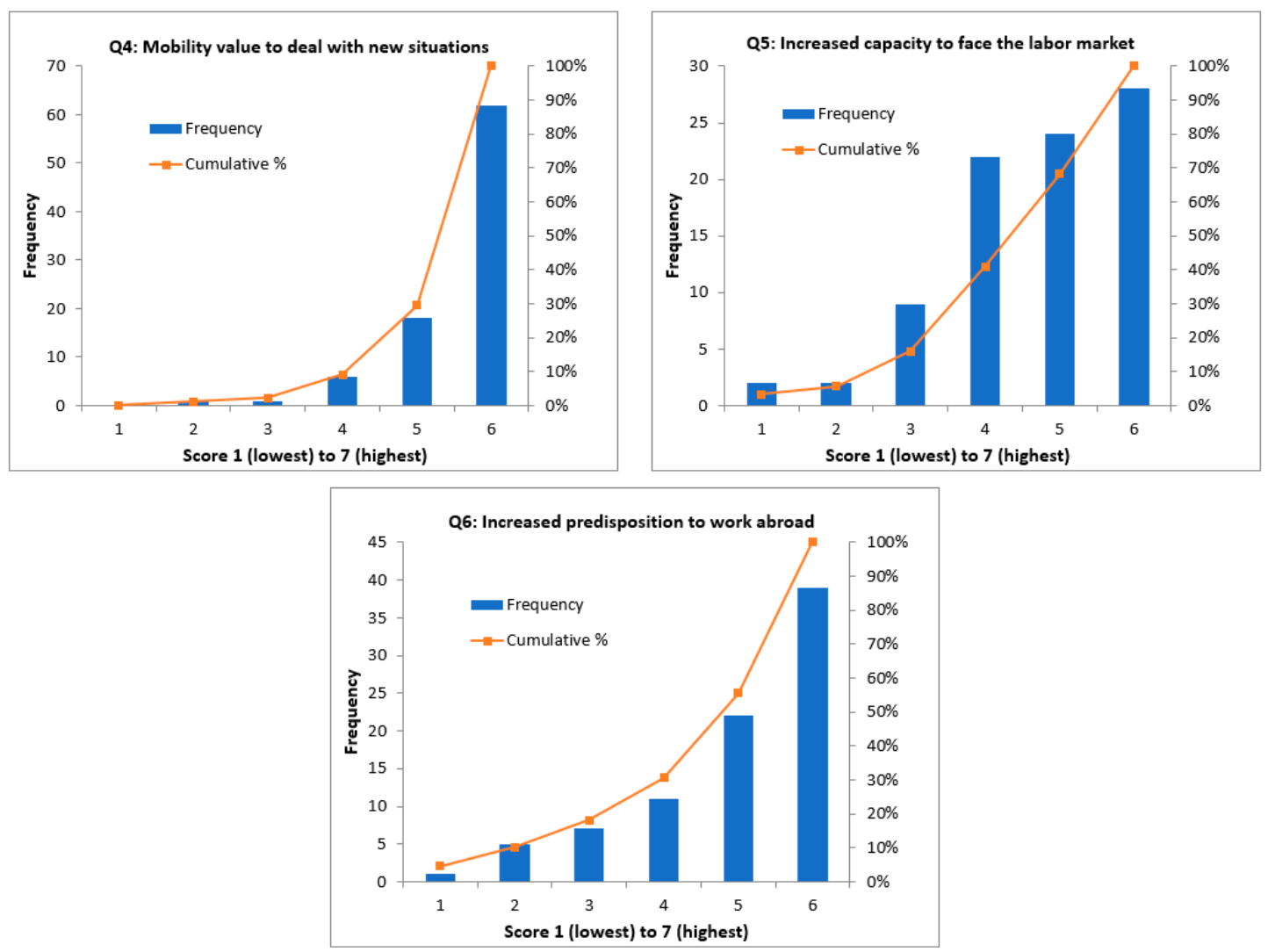

Figure 4. Feedback on Topic 2: Mobility impact on training as an Engineer.

The four questions designed for Topic 3 compare FEUP with the host university regarding institutional support, academic activities and learning methodologies in a very broad way.

Topic 3. Appreciation of the host university where mobility took place:

Q7. How do you value the institutional support received during the mobility period?

Q8. How do you value the academic environment in general (relationships with local students, extracurricular activities ... )?

Q9. How do you value the methods/means/content/evaluation of the curricular units you attended?

Q10. Would you recommend this University for mobility to future students?

Figure 5 reports the results for this third topic.

Most of the answers showed that students value the host university. Unfortunately, ten percent encountered difficulties with the institutional support either from office management as from colleagues or staff members. Consequently, those ten percent do not recommend that host university to future students.

Internationalization has become a comprehensive and holistic process, with a strong social dimension, which demands to look closer at students' needs and provision of corresponding support structures. All kind of subjective considerations would possibly be drawn from the reported results and in that sense the survey also considered an open question so that students could freely advise on their experience. Because of their subjectivity and probably lost in translation, no answer will be reported here. It is not the authors intention to try to objectively assign conclusions from the answers to this open question but mainly to manage to draw a new and more objective survey. At the time of writing, million cases of COVID-19 have been reported worldwide. Given the limited existing self-reporting instruments of student global mobility, future studies aim to develop a comprehensive questionnaire that assesses the perceived mobility capabilities under the 
global pressure of the pandemic [22]. A new survey will consider students engaging in mobility during the present pandemic situation.
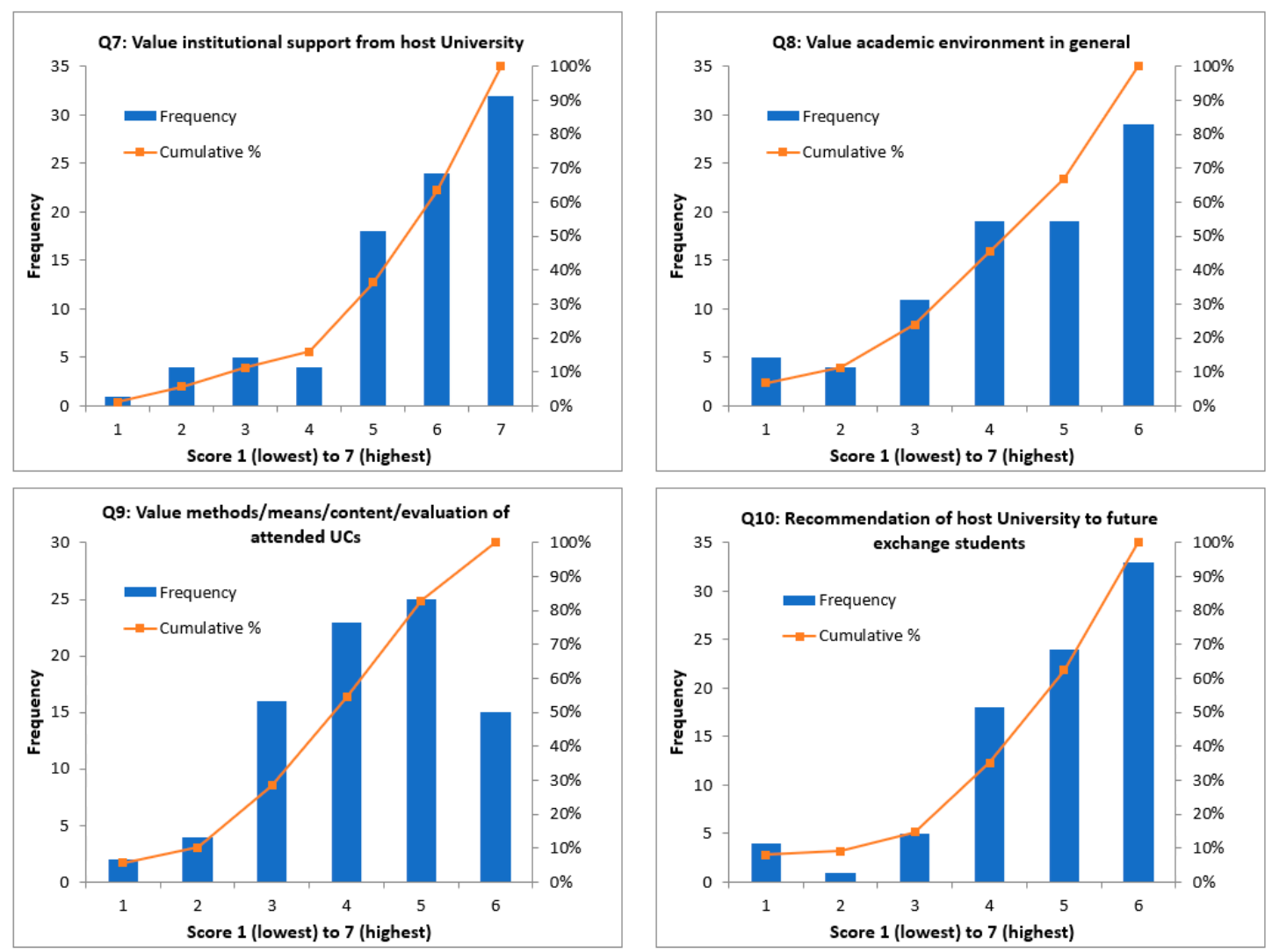

Figure 5. Feedback on Topic 3: Appreciation of the host university.

\section{Concluding Remarks}

Career is an important aspect of a young person's life reflecting the educational effort made through the period of study. Internationalization should be understood as an approach to "encountering difference" and perhaps, as a way to "encounter difference differently," that opens up possibilities for examining and re-examining biases, stereotypes, and hegemonic assumptions about ways of being and knowing [23]. Portugal is a member of the European Community and highly qualified engineers need to think globally. Students expectations to succeed are very high but the lack of a reasonable number of national qualified jobs is a reality. The results of the survey reported here show that $90 \%$ of the inquired students consider that the engaged exchange program will have a positive influence on their career. Only a short $10 \%$ did not appreciate the experience. In this context, student exchange may help to increase the level of employability, and it may turn into an advantage in the labor market competition, as an element that most employers appreciate as positive. Overall, the survey results are very favorable to continuing outgoing exchange student mobility at MIEM.

Exchange programs are e reciprocal, the number of outgoing students should balance the number of incoming students. That balance is not observed at degree level since the number of incoming students is only half the number of outgoing MIEM students. Brazilian students represent the larger class of incoming MIEM students because of international open-mindedness and clear attraction to European countries consequently leading to international networking development with Portugal because of language and cultural heritage. Industrial business model aims to act as a key driver of innovation, job creation, exports, capital security: around 80\% of European innovation and $75 \%$ of exports are 
result of industrial efforts. So, MIEM students will spread out over one hundred host Universities but MIEM does not get students from those same universities. Students from highly industrialized countries get well-payed engineering jobs and compared to students from countries with lower incomings, they demonstrate a stronger interest in staying inland [24]. Therefore, a push factor is needed to drive them into a more international environment. University investment in quality works as a pull factor attracting students. Foreign language proficiency, especially English, is considered crucial in the context of globalization and internationalization. So, with the new coming two-year master degree in Mechanical Engineer at FEUP to be fully taught in English, it is expected to attract more international students that will certainly internationally upgrade the Faculty of Engineering and the University of Porto.

Author Contributions: Conceptualization, methodology, formal analysis, investigation, C.F.C. and M.R.B.; writing—original draft preparation, C.F.C.; writing—review and editing, C.F.C. and M.R.B. Both authors have read and agreed to the published version of the manuscript.

Funding: This research received no external funding.

Institutional Review Board Statement: Not applicable.

Informed Consent Statement: Not applicable.

Data Availability Statement: The data presented in this study are available on request from the corresponding author.

Conflicts of Interest: The authors declare no conflict of interest.

\section{References}

1. de Wit, H.; Altbach, P.G. Internationalization in higher education: Global trends and recommendations for its future. Policy Rev. High. Educ. 2020, 1-19. [CrossRef]

2. Buckner, E. The Changing Discourse on Higher Education and the Nation-State, 1960-2010. High. Educ. 2016, 74, 473-489. [CrossRef]

3. Bedenlier, S.; Kondakci, Y.; Zawacki-Richter, O. Two Decades of Research into the Internationalization of Higher Education: Major Themes in the Journal of Studies in International Education (1997-2016). J. Stud. Int. Educ. 2017, 22, 108-135. [CrossRef]

4. Findler, F.; Schönherr, N.; Lozano, R.; Stacherl, B. Assessing the impacts of higher education institutions on sustainable development-An analysis of tools and indicators. Sustainability 2019, 11, 59. [CrossRef]

5. Bantanur, S.; Mukherjee, M.; Shankar, R. 2015 Emerging dimensions of sustainability in institutes of higher education in India. Int. J. Sustain. Built Environ. 2015, 4, 323-329. [CrossRef]

6. Katiliute, E.; Daunoriene, A.; Katkute, J. Communicating the sustainability issues in higher education institutions World Wide Webs. Procedia Soc. Behav. Sci. 2014, 156, 106-110. [CrossRef]

7. Teichler, U. Research on Higher Education in Europe. Eur. J. Educ. 2005, 40, 447-469. [CrossRef]

8. Bracht, O.; Engel, C.; Janson, K.; Over, A.; Schomburg, H.; Teichler, U. The Professional Value of Erasmus Mobility; Final Report Presented to the European Commission Education \& Culture; International Centre for Higher Education Research, University of Kassel: Kassel, Germany, 2006; Available online: https:/ /www.eurashe.eu/professional-higher-education-sector-calls-for-moreand-better-internationalization-for-the-future/ (accessed on 20 January 2021).

9. Parey, M.; Waldinger, F. Studying Abroad and the Effect on International Labour Market Mobility: Evidence from the Introduction of ERASMUS. Econ. J. R. Econ. Soc. 2011, 121, 194-222. [CrossRef]

10. Wei, H. An empirical study on the determinants of international student mobility: A global perspective. High Educ. 2013, 66, 105-122. [CrossRef]

11. Bouwel, L.V.; Veugelers, R. The Determinants of Student Mobility in Europe: The Quality Dimension. Eur. J. High. Educ. 2013, 3, 172-190. [CrossRef]

12. Buckner, E. The Internationalization of Higher Education: National Interpretations of a Global Model. Comp. Educ. Rev. 2019, 63, 315-336. [CrossRef]

13. Keller, J.M. Motivational design. In Encyclopaedia of Educational Media Communications and Technology, 2nd ed.; McAleese, R., Unwin, D., Eds.; Greenwood Press: Westport, CT, USA, 1988; pp. 406-409.

14. Didisse, J.; Nguyen-Huu, T.T.; Tran, T.A.D. The long walk to knowledge: On the determinants of higher education mobility to Europe. J. Dev. Stud. 2019, 55, 1099-1120. [CrossRef]

15. Tan, P.J.B.; Hsu, M.-H. Understanding the needs and criteria of employees in the electronics industry for English e-learning website programmes. In Proceedings of the 12th IEEE Conference on Industrial Electronics and Applications, Siem Reap, Cambodia, 18-20 June 2017; pp. 504-509. 
16. Tan, P.J.B. An empirical study of how the learning attitudes of college students toward English e-tutoring websites affect site sustainability. Sustainability 2019, 11, 1748. [CrossRef]

17. Tan, P.J.B. English e-learning in the virtual classroom and the factors that influence ESL (English as a Second Language): Taiwanese citizens' acceptance and use of the Modular Object-Oriented Dynamic Learning Environment. Soc. Sci. Inf. 2015, 54, 211-228. [CrossRef]

18. European Association for International Education (EAIE). 2016-2020 EAIE Strategy. 2016. Available online: https://www.eaie. org/dam/jcr:a6acb81f-6933-4734-8c1a-7efeca1796af/2016-2020\%20EAIE\%20Strategy.pdf (accessed on 20 January 2021).

19. NAFSA. “About Us". 2019. Available online: www.nafsa.org/About_Us/ (accessed on 28 December 2020).

20. IAU Strategic Plan 2016-2020. Available online: https:/ / www.iau-aiu.net/IMG/pdf/iau_strategic_plan_2016-2020 (accessed on 28 December 2020).

21. Clemente, I.M.; Giner, G.R.; Vélez, G.S. Towards Sustainability in University Education. Improving University Graduates Chances of Employability by Participation in a High Achievement Academic Program. Sustainability 2020, 12, 680. [CrossRef]

22. Wu, S.-J.; Chang, D.-F.; Sun, F.-R. Exploring College Student's Perspectives on Global Mobility during the COVID-19 Pandemic Recovery. Educ. Sci. 2020, 10, 218. [CrossRef]

23. Buckner, E.; Stein, S. What Counts as Internationalization? Deconstructing the Internationalization Imperative. J. Stud. Int. Educ. 2019, 24, 151-166. [CrossRef]

24. Oliveira, P.S.; Sommer, L. Globalization and digitalization as challenges for a professional career in manufacturing industries: Differences in awareness and knowledge of students from Brazil and Germany. Educ. Sci. 2017, 7, 55. [CrossRef] 